\title{
Testosterone Stimulates Mounting Behavior and Arginine Vasotocin Expression in the Brain of both Sexual and Unisexual Whiptail Lizards
}

\author{
K.D. Hillsman N.S. Sanderson D. Crews \\ Section of Integrative Biology, University of Texas, Austin, Tex., USA
}

\author{
Key Words \\ Lizard · POA - Sexual behavior - Testosterone - Vasopressin • \\ Vasotocin
}

\begin{abstract}
In nonmammalian vertebrates the abundance of arginine vasotocin (AVT) neurons in the brain is sexually dimorphic, a pattern that is modulated by testicular androgen. This peptide is thought to be involved in the control of male-typical mounting behaviors. The all-female desert-grasslands whiptail (Cnemidophorus uniparens) reproduces by obligate parthenogenesis and in nature no males exist, but eggs treated with aromatase inhibitor hatch into individuals (called virago C. uniparens) having testes, accessory sex structures, high circulating concentrations of androgens, and exhibiting only male-like copulatory behavior. To examine the 'sexual' dimorphism of AVT-containing neurons in these animals, we compared AVT immunoreactivity in gonadectomized control and virago $C$. uniparens, with that of gonadectomized male and female Cnemidophorus inornatus, a sexual species that is the maternal ancestor to the parthenogenetic species. Mounting behavior is elicited in both species and both sexes by testosterone, and it was predicted that the distribution and abundance of AVT cell bodies and fibers would reflect the propensity of males and females of the two species
\end{abstract}

This research was supported by NIMH 41770 to D.C. to display male-typical copulatory behavior. Since both this propensity and AVT abundance are controlled by androgens, we compared testosterone-implanted and control animals within each group. Testosterone treatment generally increased AVT abundance, except in lab-reared parthenoforms, in which testosterone treatment was the least effective in inducing male-like copulatory behavior.

Copyright $\odot 2007$ S. Karger AG, Basel

Arginine vasotocin (AVT) and its mammalian counterpart vasopressin (AVP) function in a range of maletypical behaviors in vertebrates, including aggression and courtship. In many species these sexually dimorphic behaviors correlate with the abundance of AVT/AVP neurons in various brain areas (Goodson and Bass, 2001; Panzica et al., 2001; Aragona and Wang, 2004). Administration of AVT to male roughskin newts (Taricha granulosa) enhances courtship behaviors (Moore and Miller, 1983) and males have greater numbers of AVT immunoreactive (AVT-ir) cells than do females in the bed nucleus of the stria terminalis (BNST), amygdala (AMYG), and the preoptic area (POA), all areas that are involved in regulating male-specific behaviors in this species (Moore et al., 2000); AVT also induces male-typical mounting behaviors in ovariectomized female newts, but only when given in conjunction with testosterone treatment (Thompson and Moore, 2003). In cricket frogs (Acris crepitans), males that are calling to attract females release

\section{KARGER \\ Fax +41613061234 \\ E-Mail karger@karger.ch}

www.karger.com
(C) 2007 S. Karger AG, Basel

1661-5425/07/0011-0077\$23.50/0

Accessible online at:

www.karger.com/sxd
David Crews

Section of Integrative Biology

University of Texas, Austin, TX 78712 (USA)

Tel. +1 512471 1113, Fax +1 5124716078

E-Mail crews@mail.utexas.edu 
more AVT, and thus have less AVT-immunoreactivity than non-calling satellite males (Marler et al., 1999). This difference in AVT release is thought to be responsible for the dual mating strategies utilized by this species, and is dependent at least in part on differences in testosterone levels between the two male morphs (Houck and Woodley, 1995). Male bullfrogs (Rana catesbeiana) also have a greater density of AVT-ir cells and fibers in the AMYG and the habenular nucleus than do female bullfrogs (Boyd et al., 1992), and castration decreases the amount of AVT in several brain regions, indicating that steroid hormones are important for maintenance of AVT concentrations (Boyd, 1994a). Thus, it is clear that testosterone is necessary for the initiation and continuation of calling behavior and appears to influence and be influenced by AVT to activate these behaviors (Wilczynski et al., 2005). In the Japanese quail (Coturnix japonica) mounting behavior is exhibited only by males and is dependent upon androgen. This sexual dimorphism in behavior is paralleled by differences in AVT containing neurons and fibers with male quail showing a dense steroid-sensitive network of AVT-ir cell bodies and fibers in the preoptic area, BNST and the lateral septum (Panzica et al., 1998, 1999, 2001).

Whiptail lizards (genus Cnemidophorus) afford a means to investigate the evolution of neuroendocrine mechanisms controlling sex-typical behaviors because a direct ancestor-descendant phylogeny is present. Approximately one-third of extant whiptail lizard species are all-female (parthenogenetic) species that resulted from hybrid unions of sexual species (Wright, 1993). For example, the parthenogenetic desert-grasslands whiptail (Cnemidophorus uniparens) descended from an initial hybridization event between two sexually reproducing species, the rusty rumped whiptail (Cnemidophorus burti) and the little striped whiptail (Cnemidophorus inornatus) and a subsequent back cross of the diploid parthenoform with C. inornatus (Wright, 1993). Consequently, two-thirds of the triploid genome of the descendant parthenogenetic species is derived from $C$. inornatus, the maternal ancestral species.

In C. inornatus the males display a genus-typical courtship and mating posture, while females only exhibit receptive behavior that is restricted to the preovulatory stage of ovarian activity. In C. uniparens each individual displays both male-like mounting and female-like receptivity depending upon ovarian state (Crews, 2005). This display of male-like mounting behavior in the absence of circulating androgens challenges various assumptions about the relationship between hormones, brain, and behavior. Neither female C. inornatus nor C. uniparens se- crete androgens (Moore et al., 1985; Moore and Crews, 1986), although treatment with exogenous androgen will reliably stimulate robust mounting behavior in both (Lindzey and Crews, 1986; Wade et al., 1993).

As in all vertebrate species studied to date, lesion and intrahypothalamic steroid hormone implantation studies reveal the preoptic area (POA) and anterior hypothalamus $(\mathrm{AH})$ to be important areas for the display of mounting behaviors in both the sexual and the unisexual species of whiptail lizards (reviewed in Crews, 2005). Further, the $\mathrm{POA}$ and $\mathrm{AH}$ exhibit increased metabolic activity during mounting and pseudocopulatory behavior in the sexual and unisexual species, respectively (Rand and Crews, 1994). The POA/AH is larger in male C. inornatus than in female $C$. inornatus, a sexual dimorphism regulated by testosterone in males (Crews et al., 1990). However, the $\mathrm{POA} / \mathrm{AH}$ of the parthenogenetic C. uniparens resembles that of the female $C$. inornatus in both volume and soma area and does not change after ovulation, when the malelike pseudocopulatory behavior is exhibited (Crews et al., 1990; Wade and Crews, 1991, 1992). Importantly, treatment with exogenous androgen does not change the size of the POA/AH in either female C. inornatus or C. uniparens even though it completely changes the nature and frequency of behavior exhibited (Crews, 2005).

Although only female-like individuals exist normally in the parthenogenetic species, it is possible to create male-like individuals (called viragos) by treating C. uniparens eggs early in development with aromatase inhibitor (Wibbels and Crews, 1994; Wennstrom and Crews 1995). These animals have testes, active renal sex segments (an accessory sex structure homologous to the seminal vesicles), high circulating concentrations of androgens, produce motile sperm, and only display male-typical sexual behavior. However, the virago does not exhibit an enlarged POA/AH as do males of the ancestral species (Wennstrom et al., 1999). The virago also does not show another sexually dimorphic response characteristic of the ancestral sexual species, namely, upregulation of progesterone receptor in the ventromedial hypothalamus in response to exogenous estrogen (Wennstrom et al., 2003).

Based on the established involvement of AVT in mounting behavior in a variety of vertebrates we predicted that this hormone would exhibit a pattern of expression correlating with the display of male-like behavior, i.e., be greater in those animals in which male-like behavior was induced by androgens. The purpose of this experiment was to establish the distribution and abundance of AVT neurons in the brain of (a) adult male and female C. inornatus and (b) adult virago and normal 
C. uniparens that had been manipulated as eggs. To evaluate the role of testosterone in the regulation of AVT abundance, all animals were gonadectomized and implanted with either a blank silastic capsule or one containing testosterone. It was further predicted that testosterone would increase the abundance of AVT-ir neurons in the POA, AH, and the BNST. Our results indicate this to be the case.

\section{Materials and Methods}

\section{Animals}

Adult C. inornatus were captured in West Texas, transported to the laboratory at the University of Texas, Austin, and grouphoused in glass terraria until the initiation of the experiment (as described in Gustafson and Crews, 1981). Adult C. uniparens were captured in Arizona or New Mexico and housed in the same manner, while another group was raised from eggs that were laid in the laboratory. In the latter instance, eggs (average of 2-3 eggs in a clutch) were placed individually in plastic cups containing a 1:1 sand/water mixture. Eggs from each of the clutches were treated with $1 \mu$ l of either absolute ethanol or the same volume of ethanol containing $1 \mu \mathrm{g}$ of the aromatase inhibitor (AI) CGS 16949A (fadrozole) seven days after oviposition. All treatments were on the eggshell surface (Wibbels and Crews, 1994; Wennstrom and Crews, 1995). This AI treatment produces individuals who lack female sexual characteristics, but have testes, produce sperm, and mount receptive females; these phenotypically male C. uniparens individuals are hereafter referred to as viragos and the ethanoltreated parthenogens as parthenoforms. Hatchlings were individually housed and allowed to grow to maturity, as described in Wennstrom and Crews (1995).

\section{Treatment and Tissue Fixation}

Twenty-seven adult $C$. inornatus (13 females and 14 males, all field-caught), and 34 adult C. uniparens (16 field-caught parthenogens, 10 ethanol-treated parthenoforms, and 8 virago $C$. uniparens) were gonadectomized and implanted with $10 \mathrm{~mm}$ silastic implants (blank or testosterone, o.d. 1.96, i.d. $1.47 \mathrm{~mm}, \mathrm{He}-$ lix Medical inc, Carpinteria, CA). This length of implant has been found to produce physiological concentrations of circulating testosterone in male C. inornatus (Lindzey and Crews, 1986).

After six weeks, animals were tested with an estrogen primed receptive female to assess mounting behavior. Each testosteroneimplanted animal was yoked to a blank-implanted animal, to control for differences in mount latencies. After all of the animals implanted with testosterone had mounted, they and the corresponding blank-implanted animals were sacrificed by rapid decapitation and heads were put in $4 \%$ paraformaldehyde overnight at $4^{\circ} \mathrm{C}$. The next day, the brains were removed from the skulls and placed in $4 \%$ paraformaldehyde for $24 \mathrm{~h}$ at $4^{\circ} \mathrm{C}$, followed by $20 \%$ sucrose for $24 \mathrm{~h}$ at $4^{\circ} \mathrm{C}$. Brains were then frozen over dry ice and sectioned on a Microm HM $500 \mathrm{OM}$ cryostat at $40 \mu \mathrm{m}$. Free-floating sections were put into 12-well plates containing cold Phosphate Buffered Saline (PBS) until used for AVT immunohistochemistry (not more than two weeks).

Testosterone, Mounting Behavior and AVT in Whiptail Lizards

\section{Histology}

Sections from all brains were run together using the same antibody. All wells were rinsed in fresh cold PBS for $20 \mathrm{~min}$ and then placed into $3 \% \mathrm{H}_{2} \mathrm{O}_{2} /$ methanol mixture (3:1) for $25 \mathrm{~min}$. After rinsing in cold PBS for $30 \mathrm{~min}$, sections were blocked in $2 \%$ normal goat serum and $9 \%$ avidin in PBS with triton-X for $1 \mathrm{~h}$. After rinsing for another $30 \mathrm{~min}$, slices were incubated with rabbit antivasopressin primary antibody at $4{ }^{\circ} \mathrm{C}$ (MP Biomedicals, formerly ICN Biomedicals, 1:5000). This antibody has been used in several non-mammalian species with success (see Boyd et al., 1992; Marler et al., 1999). After $48 \mathrm{~h}$, sections were again rinsed in cold PBS for $30 \mathrm{~min}$ and then treated with goat anti-rabbit secondary antibody for $1 \mathrm{~h}$ (Vector, 1:1,000). Sections were rinsed, then put into ABC (Vectastain Elite), rinsed again, and processed with diaminobenzadine. After rinsing in cold PBS overnight, sections were mounted onto slides and coverslipped.

\section{Stereology}

In preliminary studies using intact animals, it was determined that three main regions show AVT-ir in these two lizard species. These areas (POA, BNST, and $\mathrm{AH}$ ) were defined in extensive previous research on the neuroendocrinology and neuroanatomy of these and related species (Young et al., 1994; Crews, 2005). Sections containing the POA had a distinct anterior commissure, complete optic chiasm, and usually BNST cells. The AH included cell bodies that were caudal to the anterior commissure, but in the same horizontal plane as POA cells.

Slides were coded so that the researcher was blind to the animal's group. The number of AVT-ir cells was counted using Stereo Investigator (Microbrightfield, Williston, VT). Following Woolley et al. (2004), cell numbers were estimated by counting every cell on every section in which the nucleus was evident, since the extremely small size of the lizard preoptic area and the concentration of the AVT-ir cells in a small periventricular zone make more sophisticated counting techniques unsuitable. For those slides on which the quality of the tissue processing or the staining did not permit this exhaustive counting procedure, the individual was not included in our analysis.

\section{Fiber Density Analysis}

The density of AVT immunoreactive fibers in the preoptic area was estimated by comparing the optical density of the fiberrich zone with adjacent areas of the preoptic area devoid of fibers. Images were captured on a Leica microscope attached to a Dell computer under constant illumination and camera settings for all brains. Resulting images were analyzed using ImageJ software (Abramoff et al., 2004) on a Macintosh G4. ImageJ was used to delineate an area of interest corresponding to the fiber tracts or to adjacent control areas, and to measure the optical density in comparison with a Kodak step tablet (Rasband, 1997-2005).

\section{Data Analysis}

Estimated cell numbers from all individuals were analyzed in a three-way (sex $\times$ hormone $\times$ species) ANOVA, and planned comparisons between testosterone and blank-implanted animals were conducted using the GLM procedure of the SAS program on the University of Texas Windows Server. Effect size was also determined to measure the magnitude of treatment effects. Cohen's $d$ is a standardized difference between means of the experimental and control group and is independent of sample size 


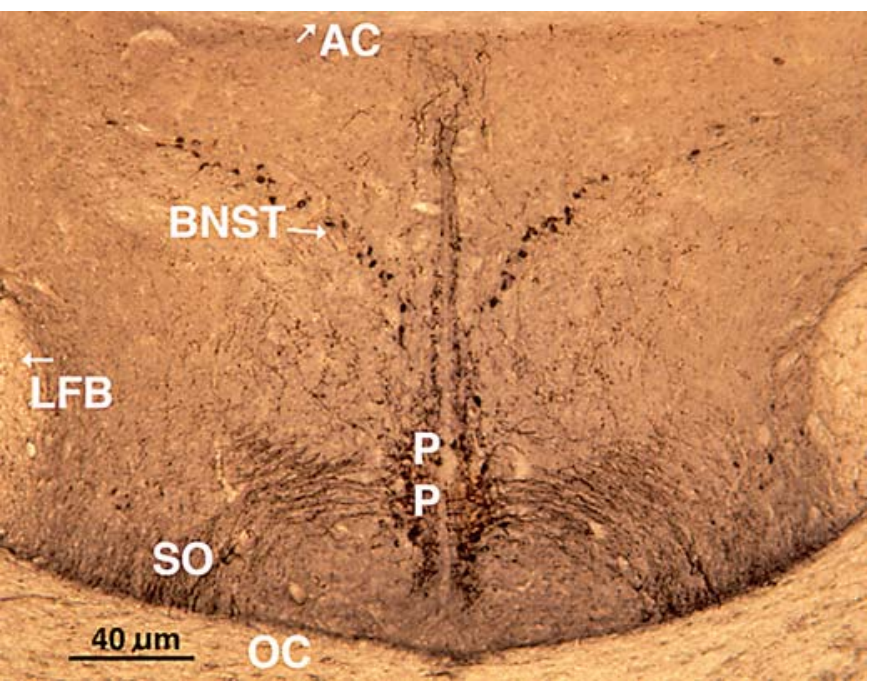

Fig. 1. Arginine vasotocin immunoreactive cells (AVT-ir) and fibers in the preoptic area and the bed nucleus of the stria terminalis (BNST) in a virago Cnemidophorus uniparens receiving a blank implant. Other abbreviations: $\mathrm{AC}=$ anterior commissure; $\mathrm{LFB}=$ lateral forebrain bundle; $\mathrm{OC}=$ optic chiasm; $\mathrm{SO}=$ supraoptic nucleus; $\mathrm{PP}=$ periventricular preoptic area.

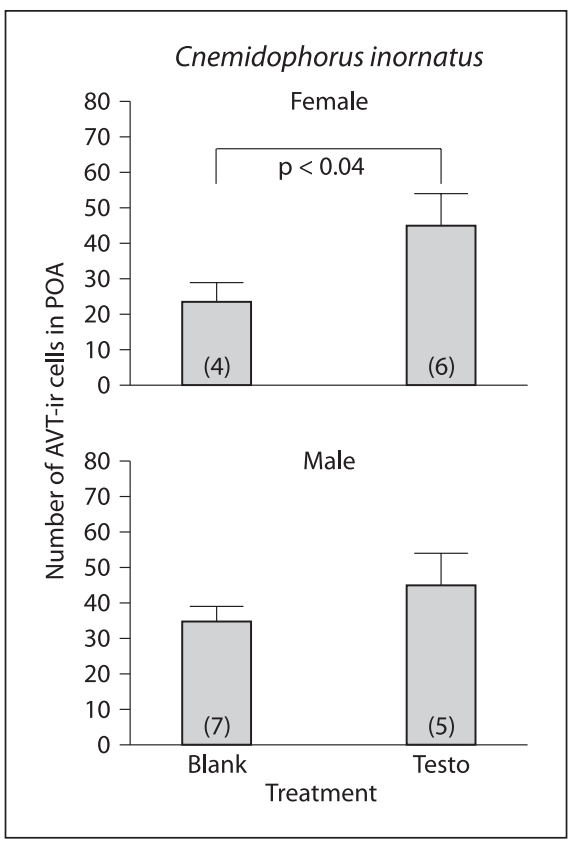

Fig. 2. Testosterone treatment increases abundance of arginine vasotocin immunoreactive cells (AVT-ir) in the preoptic area (POA) of Cnemidophorus inornatus. Effect size is large in both females (top panel) and males (bottom panel), but reaches statistical significance only in females. Mean and standard error of groups shown with number of individuals indicated in parentheses. Significant contrasts indicated.
(Cohen, 1988). An effect size of 0.2 is equivalent to Cohen's standard SMALL and indicates that the mean of the treated group is at the 58th percentile of and sharing $85 \%$ overlap with the untreated group. An effect size of 1.7 is equivalent to Cohen's standard LARGE and indicates that the mean of the treated group is at the 95.5 percentile and sharing $25 \%$ overlap of the untreated group.

\section{Results}

\section{Distribution of AVT-ir Cell Bodies and Fibers}

Arginine vasotocin immunoreactive cell bodies were located in the periventricular and medial POA, $\mathrm{AH}$, BNST, and supraoptic nucleus (fig. 1). While AVT-ir fibers co-existed with the cell bodies in these areas, fibers were also observed in areas lacking cell bodies such as the nucleus accumbens, lateral septum, and torus semicircularis; in the POA, a prominent lateral projection, apparently arising from the AVT-ir cell bodies in the PvPOA, and a more rostroventrally oriented tract of fibers passing approximately through the region of the SO was also apparent (fig. 1).

\section{AVT Expression in the POA}

An overall effect of hormone was revealed by the three way ANOVA $(\mathrm{F}=4.34, \mathrm{df}=1, \mathrm{p}<0.04)$, with testosterone-individuals having more AVT-ir cells in the preoptic area than blank-implanted animals. None of the other main effects or interactions were significant. Although the group-means were higher for the testosterone-implanted group in every case, planned comparisons of testosterone-implanted versus blank-implanted animals within each species/sex group revealed that the effect of testosterone treatment was statistically significant only in the female $C$. inornatus ( $<<0.04$ ) (fig. 2 ) and virago C. uniparens $(\mathrm{p}<0.05)$ (fig. 3). The effect sizes for these two comparisons were medium and high, respectively (table 2). In neither male C. inornatus nor parthenoform C. uniparens was the increase significant.

No differences between any groups were detected in the density of AVT immunoreactive fibers in the POA.

\section{AVT Expression in the AH and BNST}

In both species of whiptail lizards, implantation with testosterone failed to cause a significant increase in the number of AVT-ir cells in the AH or BNST. There was no significant difference in AVT immunoreactivity between gonadectomized, blank-implanted male and female $C$. inornatus, or similarly treated viragos and parthenoforms (table 1). 


\section{Discussion}

Our results are consistent with the conclusion that sexual dimorphisms in AVT distribution are determined largely by circulating androgen levels, rather than by hormonal effects determined by gonadal sex during development, or by sexual genotype. In both species and in both gonadal sexes the effect of testosterone was to increase AVT expression in the preoptic area, although statistically significant increases were detected only in the gonadally female $C$. inornatus and the gonadally male $C$. uniparens (viragos). Neither the effect of sex or species approached statistical significance in the ANOVA, nor was there an interaction between sex and hormone, suggesting that both males and females will express maletypical levels of AVT if exposed to male-typical levels of testosterone. Although species differences exist in the localization of immunoreactive AVT-containing cell bodies and fibers in the brain of nonmammalian vertebrates, in all species studied to date AVT-ir and/or AVT mRNA is found in the nucleus accumbens, supraoptic nucleus, preoptic area, septum, nucleus of the stria terminalis, and the torus semicircularis (fish: Foran and Bass, 1998; Godwin et al., 2000; Parhar et al., 2001; Semsar and Godwin, 2003; amphibians: Boyd, 1994a; Lowry et al., 1997; reptiles: Goossens et al., 1979; Stoll and Voorn, 1985; Thepen et al., 1987; Smeets et al., 1990; Propper et al.,

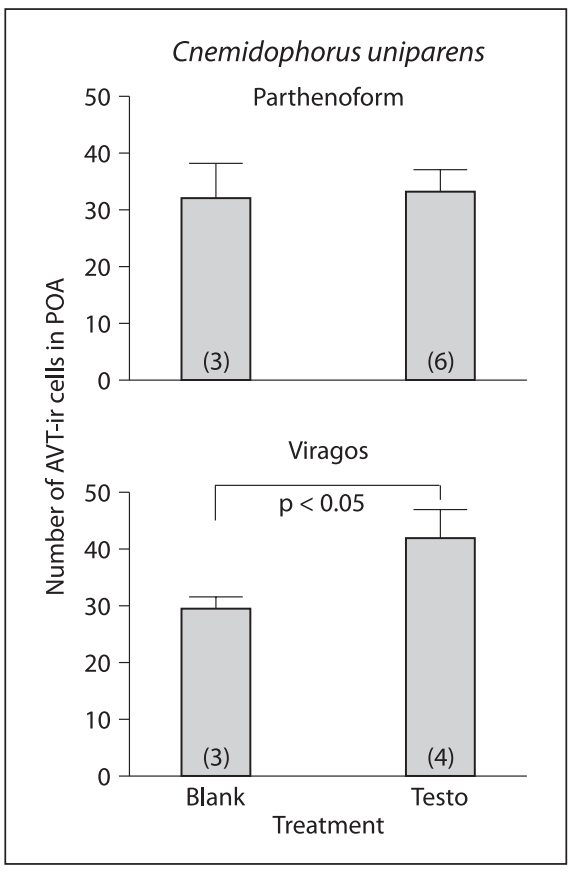

Fig. 3. Testosterone treatment increases abundance of arginine vasotocin immunoreactive cells (AVT-ir) in the preoptic area (POA) of Cnemidophorus uniparens treated as embryos with aromatase inhibitor (viragos) (bottom panel), but not in C. uniparens treated as embryos with ethanol (parthenoform) (top panel). Mean and standard error of groups shown with number of individuals indicated in parentheses. Significant contrasts indicated.

Table 1. Abundance of arginine vasotocin immunoreactive (AVT-ir) cells in the preoptic area (POA), anterior hypothalamus (AH) and bed nucleus of the stria terminalis (BNST)

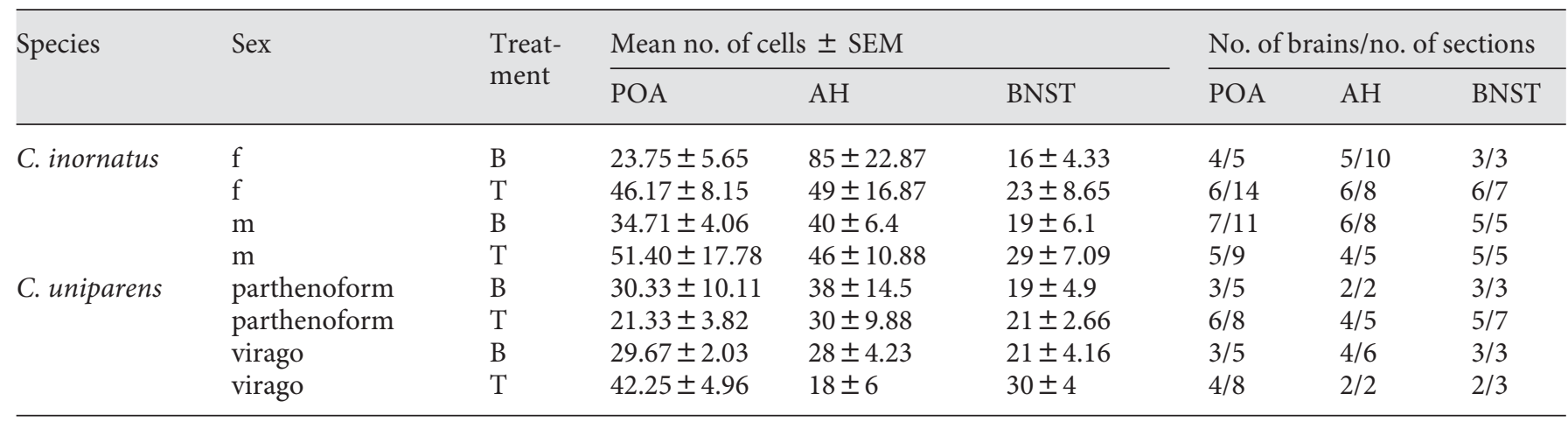

Adult Cnemidophorus inornatus males and females were gonadectomized and implanted with an empty (B) or testosterone-filled (T) silastic capsule. Cnemidophorus uniparens were treated in ovo with either aromatase inhibitor (virago) or ethanol (parthenoform), then gonadectomized in adulthood and implanted with an empty or testosterone-filled silastic capsule. Average number of cells in each brain area indicated with standard error. Number of brains with total number of sections containing AVT-ir cells are indicated in the last column. 
Table 2. Cohen's $d$ and effect size for comparisons of abundance of arginine vasotocin immunoreactive cells in the preoptic area of Cnemidophorus inornatus males and females that had been gonadectomized and implanted with an empty or testosterone-filled silastic capsule in adulthood

\begin{tabular}{lllll}
\hline Group comparison & & $\begin{array}{l}\text { Cohen's d } \\
\text { effect size }\end{array}$ & $\begin{array}{l}\text { Percentile } \\
\text { standing }\end{array}$ & Overlap (\%) \\
\hline C. inornatus & female + B vs. female + T & 1.4 & 91.9 & 32 \\
& male + B vs. male + T & 0.6 & 73.0 & 62 \\
& female + B vs. male + B & 1.0 & 84.0 & 45 \\
& female + T vs. male + T & 0.2 & 58.0 & 85 \\
C. uniparens & parth. + B vs. parth. + T & 1.3 & 90.0 & 35 \\
& virago + B vs. virago + T & 1.7 & 95.5 & 25 \\
C. inornatus vs. C. uniparens & parth. + B vs. virago + B & 0.7 & 76.0 & 57 \\
& parth. + T vs. virago + T & 2.2 & 97.7 & 19 \\
& female + B vs. parth. + B & 1.0 & 84.0 & 46 \\
& female + T vs. parth. + T & 1.6 & 94.5 & 27 \\
& male + B vs. virago + B & 0.6 & 73.0 & 63 \\
& male + T vs. virago + T & 0.3 & 62.0 & 70
\end{tabular}

Cnemidophorus uniparens were treated in ovo with aromatase inhibitor (virago) or ethanol (parthenoform), then gonadectomized in adulthood and implanted with an empty (B) or testosterone-filled (T) silastic capsule. An effect size of 0.2 is equivalent to Cohen's standard SMALL and indicates that the mean of the treated group is at the 58th percentile and sharing $85 \%$ overlap of the untreated group. An effect size of 1.7 is equivalent to Cohen's standard LARGE and indicates that the mean of the treated group is at the 95.5 percentile and sharing $25 \%$ overlap of the untreated group.

1992; birds: Kiss et al., 1987; Viglietti-Panzica et al., 1994; Jurkevich et al., 1996, 1997, 1999, 2001; Panzica et al., 1998, 1999, 2001; Kimura et al., 1999; Panzica and Viglietti-Panzica, 1999; Grossmann et al., 2002). A similar distribution of AVT-ir cell bodies and fibers was found in the brain of both whiptail lizard species. Arginine vasoctocin-ir containing cell bodies were located in the periventricular and medial POA and anterior hypothalamus, areas that also express high concentrations of $\mathrm{PR}$, but also contain ER- and AR-expressing neurons in whiptail lizards (Young et al., 1994). The AVT-ir cell bodies in the BNST formed a prominent, wing-like constellation across the lateral preoptic and hypothalamic region. The supraoptic nucleus (SO) contained dense AVT-ir fiber innervation and, in some sections, also contained some cell bodies; this area also contains neurons expressing ER (Young et al., 1994). This coincidence of AVT-ir and ER in the SO has also been reported by Propper et al. (1992) for the green anole lizard (Anolis carolinensis). In this species the concentration of AVT within this nucleus varied with ovarian state, being highest in females having large preovulatory follicles. AVT-ir fibers were located in the nucleus accumbens, an area that also contains both PR- and AR-labeled cells (Young et al., 1994). There was also robust fiber staining in the lateral septum and in the torus semicircularis, areas that also contain AR-labeled cells and ER and PR expressing neurons, respectively.

Sexual dimorphisms have been reported in the distribution and density of AVT containing neurons, in the intensity of AVT-ir staining, or in the distribution of AVT mRNA containing cells in fish (Foran and Bass, 1998), amphibians (Boyd et al., 1992; Boyd, 1994a), reptiles (Stoll and Voorn, 1985; Thepen et al., 1987; Smeets et al., 1990; Propper et al., 1992) and birds (Voorhuis et al., 1988; Viglietti-Panzica et al., 1994; Jurkevich et al., 1997, 1999, 2001; Aste et al., 1998; Kimura et al., 1999; Panzica and Viglietti-Panzica, 1999; Panzica et al., 2001; Grossmann et al., 2002). A similar dimorphism was found in the sexual species of whiptail lizard, C. inornatus. In amphibians (Boyd, 1994a; Moore et al., 2000) and birds (Voorhuis et al., 1988; Viglietti-Panzica et al., 1994; Kimura et al., 1999; Panzica et al., 1999, 2001) these dimorphic patterns of distribution are modulated by androgen, either acting directly or via conversion to estrogen. Further, these dimorphisms appear early in life (Robinzon et al., 1992; Boyd, 1994b; Aste et al., 1998; Panzica et al., 1998, 1999; Jurkevich et al., 1999, 2001; Panzica and Viglietti-Panzica, 1999). 
Our results suggest that the AVT systems in two closely related species of whiptail lizards (C. inornatus and $C$. uniparens) respond to exogenous testosterone treatment in adulthood. Comparison of gonadectomized, blankimplanted male and female C. inornatus indicate a possible dimorphism in levels of AVT-ir. When C. inornatus are gonadectomized as adults, testosterone treatment increased the number of AVT-ir neurons in both sexes to comparable levels.

Among individuals that had been treated prenatally with aromatase inhibitor and consequently having a male phenotype (viragos), testosterone treatment increased AVT-ir neuron numbers in the POA compared to blankimplanted viragos. Sexual differentiation may not be attributed solely to the actions of sex hormones, as there is evidence to suggest that genetic sex may also influence neural phenotypes (reviewed in Arnold et al., 2003). For example, genetically mutated male mice lacking Sry, the gene that initiates testes formation, on their Y chromosome, but having an Sry transgene on an autosomal chromosome (XY- Sry) have a higher density of vasopressin (AVP) fibers in the lateral septum than do males with two $\mathrm{X}$ chromosomes and Sry autosomal expression $\left(\mathrm{XX}^{+}\right.$Sry).
Similarly, female mice with a Y chromosome lacking Sry $\left(\mathrm{XY}^{-}\right)$have a higher density of AVP fibers than normal females (XX) (De Vries et al., 2002). These results suggest that the presence of a $\mathrm{Y}$ chromosome alone may influence AVP expression. The present results do not support an involvement of genetic sex in AVT expression in these species or the endocrine history of the individual (developing as a male vs. a female), but do support the interpretation that the presence of testosterone in the circulation at the time determines AVT abundance.

In conclusion, our results indicate a simple, activational hormonal effect of testosterone on the AVT system of whiptail lizards, which is also independent of neuroendocrine history or genetic sex, and point to the whiptail lizard as a valuable resource in the understanding of such genetic influences on brain development.

\section{Acknowledgements}

We thank Andrea Gore for editorial comments and Brian Dias and Di Wu for technical assistance. We also thank Novartis Pharma AG, Basel, Switzerland for the gift of the CGS 16949A (Fadrozole).

\section{References}

Abramoff MD, Magelhaes PJ, Ram SJ: Image processing with ImageJ. Biophotonics International 11:36-42 (2004).

Aragona BJ, Wang Z: The prairie vole (Microtus ochrogaster): an animal model for behavioral neuroendocrine research on pair bonding. ILAR J 45:35-45 (2004).

Arnold AP, Rissman EF, De Vries GJ: Two perspectives on the origin of sex differences in the brain. Ann NY Acad Sci 1007:176-188 (2003).

Aste N, Balthazart J, Absil P, Grossmann R, Mulhbauer E, et al: Anatomical and neurochemical definition of the nucleus of the stria terminalis in Japanese quail (Coturnix japonica). J Comp Neurol 396:141-157 (1998).

Boyd SK: Gonadal steroid modulation of vasotocin concentrations in the bullfrog brain. Neuroendocrinol 60:150-156 (1994a).

Boyd SK: Development of vasotocin pathways in the bullfrog brain. Cell Tissue Res 276:593602 (1994b).

Boyd SK, Tyler CJ, De Vries GJ: Sexual dimorphism in the vasotocin system of the bullfrog (Rana catesbeiana). J Comp Neurol 325:313325 (1992).

Cohen J: Statistical Power Analysis for the Behavioral Sciences, 2nd ed. (Lawrence Erlbaum Associates, Hillsdale 1988).
Crews D: Evolution of neuroendocrine mechanisms that regulate sexual behavior. Trends Endocrinol Metab 16:354-361 (2005).

Crews D, Wade J, Wilczynski W: Sexually dimorphic areas in the brain of whiptail lizards. Brain Behav Evol 36:262-270 (1990).

De Vries GJ, Rissman EF, Simerly RB, Yang LY, Scordalakes EM, et al: A model system for study of sex chromosome effects on sexually dimorphic neural and behavioral traits. J Neurosci 22:9005-9014 (2002).

Foran CM, Bass AH: Preoptic AVT immunoreactive neurons of a teleost fish with alternative reproductive tactics. Gen Comp Endocrinol 111:271-282 (1998).

Godwin J, Sawby R, Warner RR, Crews D, Grober MS: Hypothalamic arginine vasotocin mRNA abundance variation across sexes and with sex change in a coral reef fish. Brain Behav Evol 55:77-84 (2000)

Goodson JL, Bass AH: Social behavior functions and related anatomical characteristics of vasotocin/vasopressin systems in vertebrates. Brain Res Rev 35:246-265 (2001).

Goossens N, Dierickx K, Vandesande F: Immunocytochemical localization of vasotocin and mesotocin in the hypothalamus of lacertilian reptiles. Cell Tissue Res 200:223-227 (1979).
Grossmann R, Jurkevich A, Kohler A: Sex dimorphism in the avian arginine vasotocin system with special emphasis to the bed nucleus of the stria terminalis. Comp Biochem Physiol A Mol Integr Physiol 131:833-837 (2002)

Gustafson JE, Crews D: Effect of group size and physiological state of a cagemate on reproduction in the parthenogeneticlizard Cnemidophorus uniparens (Teiidae). Behav Ecol Sociobiol 8:267-272 (1981).

Houck LD, Woodley SK: Field studies of steroid hormones and male reproductive behavior in amphibians, in Heatwole H, Sullivan BK (eds): Amphibian Biology, pp 677-703 (Surry Beatty \& Sons PTY Limited, Chipping Norton 1995).

Jurkevich A, Barth SW, Aste N, Panzica G, Grossmann R: Intracerebral sex differences in the vasotocin system in birds: possible implication in behavioral and autonomic functions. Horm Behav 30:673-681 (1996).

Jurkevich A, Barth SW, Grossmann R: Sexual dimorphism of arg-vasotocin gene expressing neurons in the telencephalon and dorsal diencephalon of the domestic fowl. An immunocytochemical and in situ hybridization study. Cell Tissue Res 287:69-77 (1997). 
Jurkevich A, Barth SW, Kuenzel WJ, Kohler A, Grossmann R: Development of sexually dimorphic vasotocinergic system in the bed nucleus of stria terminalis in chickens. J Comp Neurol 408:46-60 (1999).

Jurkevich A, Grossmann R, Balthazart J, Viglietti-Panzica C: Gender-related changes in the avian vasotocin system during ontogeny. Microsc Res Tech 55:27-36 (2001).

Kimura T, Okanoya K, Wada M: Effect of testosterone on the distribution of vasotocin immunoreactivity in the brain of the zebra finch, Taeniopygia guttata castanotis. Life Sci 65:1663-1670 (1999).

Kiss JZ, Voorhuis TA, van Eekelen JA, de Kloet ER, de Wied D: Organization of vasotocinimmunoreactive cells and fibers in the canary brain. J Comp Neurol 263:347-364 (1987).

Lindzey J, Crews D: Hormonal control of courtship and copulatory behavior in male Cnemidophorus inornatus, a direct sexual ancestor of a unisexual, parthenogenetic lizard. Gen Comp Endocrinol 64:411-418 (1986).

Lowry CA, Richardson CF, Zoeller TR, Miller LJ, Muske LE, Moore FL: Neuroanatomical distribution of vasotocin in a urodele amphibian (Taricha granulosa) revealed by immunohistochemical and in situ hybridization techniques. J Comp Neurol 385:43-70 (1997).

Marler CA, Boyd SK, Wilczynski W: Forebrain arginine vasotocin correlates of alternative mating strategies in cricket frogs. Horm Behav 36:53-61 (1999).

Moore FL, Miller LJ: Arginine vasotocin induces sexual behavior of newts by acting on cells in the brain. Peptides 4:97-102 (1983).

Moore FL, Richardson C, Lowry CA: Sexual dimorphism in numbers of vasotocin-immunoreactive neurons in brain areas associated with reproductive behaviors in the roughskin newt. Gen Comp Endocrinol 117:281298 (2000).

Moore MC, Crews D: Sex steroid hormones in natural populations of a sexual whiptail lizard Cnemidophorus inornatus, a direct evolutionary ancestor of a unisexual parthenogen. Gen Comp Endocrinol 63:424-430 (1986).

Moore MC, Whittier JM, Crews D: Sex steroid hormones during the ovarian cycle of an allfemale, parthenogenetic lizard and their correlation with pseudosexual behavior. Gen Comp Endocrinol 60:144-153 (1985).

Panzica GC, Viglietti-Panzica C: Gonadal steroid-dependent neuronal circuitries in avian limbic and preoptic regions. Eur J Morphol 37:112-116 (1999)

Panzica GC, Castagna C, Viglietti-Panzica C, Russo C, Tlemcani O, Balthazart J: Organizational effects of estrogens on brain vasotocin and sexual behavior in quail. J Neurobiol 37:684-699 (1998)
Panzica G, Pessatti M, Viglietti-Panzica C Grossmann R, Balthazart J: Effects of testosterone on sexually dimorphic parvocellular neurons expressing vasotocin $\mathrm{mRNA}$ in the male quail brain. Brain Res 850:55-62 (1999).

Panzica GC, Aste N, Castagna C, Viglietti-Panzica C, Balthazart J: Steroid-induced plasticity in the sexually dimorphic vasotocinergic innervation of the avian brain: Behavioral implications. Brain Res Rev 37:178-200 (2001).

Parhar IS, Tosaki H, Sakuma Y, Kobayashi M: Sex differences in the brain of goldfish: gonadotropin-releasing hormone and vasotocinergic neurons. Neuroscience 104:10991110 (2001)

Propper CR, Jones RE, Lopez KH: Distribution of arginine vasotocin in the brain of the lizard Anolis carolinensis. Cell Tissue Res 267: 391-398 (1992).

Rand MS, Crews D: The bisexual brain: sex behavior differences and sex differences in parthenogenetic and sexual lizards. Brain Res 663:163-167 (1994).

Rasband WS: 1997-2005. ImageJ [Internet]. US National Institutes of Health, Bethesda. Available from: http://rsb.info.nih.gov/ij/ In particular, Optical Density Calibration [Modified 2004 Nov 17; cited 2005 Jan 19]. Available from: http://rsb.info.nih.gov/ij/ docs/examples/calibration/

Robinzon B, Sayag N, Koike TI, Kinzler SL, Marks PA: Embryonic differentiation of sexual dimorphism in vasotocin and mesotocin levels in chickens. Pharmacol Biochem Behav 42:823-829 (1992).

Semsar K, Godwin J: Social influences on the arginine vasotocin system are independent of gonads in a sex-changing fish. J Neurosci 23 : 4386-4393 (2003)

Smeets WJ, Sevensma JJ, Jonker AJ: Comparative analysis of vasotocin-like immunoreactivity in the brain of the turtle Pseudemys scripta elegans and the snake Python regius. Brain Behav Evol 35:65-84 (1990).

Stoll CJ, Voorn P: The distribution of hypothalamic and extrahypothalamic vasotocinergic cells and fibers in the brain of a lizard, Gekko gecko: Presence of a sexual difference. J Comp Neurol 239:193-204 (1985).

Thepen T, Voorn P, Stoll CJ, Sluiter AA, Pool $\mathrm{CW}$, Lohman AH: Mesotocine and vasotocin in the brain of the lizard Gekko gecko: An immunocytochemical study. Cell Tissue Res 250:649-656 (1987).

Thompson RR, Moore FL: The effects of sex steroids and vasotocin on behavioral responses to visual and olfactory sexual stimuli in ovariectomized female roughskin newts. Horm Behav 44:311-318 (2003)
Viglietti-Panzica C, Aste N, Balthazart J, Panzica GC: Vasotocinergic innervation of sexually dimorphic medial preoptic nucleus of the male Japanese quail: influence of testosterone. Brain Res 657:171-184 (1994)

Voorhuis TA, Kiss JZ, de Kloet ER, de Wied D: Testosterone-sensitive vasotocin-immunoreactive cells and fibers in the canary brain. Brain Res 442:139-146 (1988).

Wade J, Crews D: The relationship between reproductive state and 'sexually' dimorphic brain areas in sexually reproducing and parthenogenetic whiptail lizards. J Comp Neurol 309:507-514 (1991).

Wade J, Crews D: Sexual dimorphisms in the soma size of neurons in the brain of whiptail lizards (Cnemidophorus species). Brain Res 594:311-314 (1992).

Wade J, Huang JM, Crews D: Hormonal control of sex differences in the brain, behavior and accessory sex structures of whiptail lizards (Cnemidophorus species). J Neuroendocrinol 5:81-93 (1993).

Wennstrom KL, Crews D: Making males from females: The effects of aromatase inhibitors on a parthenogenetic species of whiptail lizard. Gen Comp Endocrinol 99:316-322 (1995).

Wennstrom KL, Blesius F, Crews D: Volumetric analysis of sexually dimorphic limbic nuclei in normal and sex-reversed whiptail lizards. Brain Res 838:104-109 (1999).

Wennstrom KL, Gill CJ, Crews D: Sex differences in estrogen-induced progesterone and estrogen receptor mRNA in the ventromedial hypothalamus of hatchling whiptail lizards. Brain Res Dev Brain Res 145:151-157 (2003)

Wibbels T, Crews D: Putative aromatase inhibitor induces male sex determination in a female unisexual lizard and in a turtle with temperature-dependent sex determination. J Endocrinol 141:295-299 (1994)

Wilczynski W, Lynch KS, O'Bryant EL: Current research in amphibians: Studies integrating endocrinology, behavior, and neurobiology. Horm Behav 48:440-450 (2005).

Woolley SC, Sakata JT, Crews D: Evolutionary insights into the regulation of courtship behavior in male amphibians and reptiles. Physiol Behav 83:347-360 (2004).

Wright JW: Evolution of the lizards of the genus Cnemidophorus, in Wright JW (ed): Biology of Whiptail Lizards (Genus Cnemidophorus), pp 27-82 (Oklahoma Museum of Natural History, Norman 1993).

Young LJ, Lopreato GF, Horan K, Crews D: Cloning and in situ hybridization analysis of estrogen receptor, progesterone receptor, and androgen receptor expression in the brain of whiptail lizards (Cnemidophorus uniparens and C. inornatus). J Comp Neurol 347:288300 (1994) 